\title{
Consumer Behavior Intentions to Purchase Daily Needs through Online Store Channel
}

\author{
Moh. Wahyudin, Henry Yuliando, Amalia Savitri \\ Department of Agro-industrial Technology, Faculty of Agricultural Technology, Universitas Gadjah Mada, \\ Jl. Flora No. 1, Bulaksumur, Yogyakarta 55281, Indonesia \\ ${ }^{*}$ Corresponding author: Moh. Wahyudin, Email: moh.wahyudin@ugm.ac.id
}

Submission: September 2, 2019; Acceptance: June 17, 2020

\begin{abstract}
The inception of the 4.0 industrial era led to the evolution of internet information technology, which significantly changed the business sector's marketing, transaction, and payment systems into online stores. This new marketplace is an important business infrastructure used to develop marketing strategies in this technological era. Therefore, it enables companies or enterprises, including those in the retail sector, to remotely sell daily products, such as cooking needs, foods, snacks, beverages, toiletries, and laundries through various online platforms. Furthermore, these companies need to creatively and anticipatively participate in the various trading competition by having an online shopping channel. This study aims to measure consumer behavior intention in using the online store channel to purchase daily needs products in order to determine the influence of convenience and risk transactions on behavioral intentions. Data were obtained from respondents that consistently make use of online stores channel. The result showed that consumers' ease and convenience during transactions, especially in terms of payment and delivery service, have a positive and significant effect on their attitude and behavioral intention to use online store channel to purchase daily needs products.
\end{abstract}

Keywords: Consumer behavior; daily needs; online store; apps store; marketplace

\section{INTRODUCTION}

The evolution of the 4.0 industrial era has led to a more competitive business world that is not limited by time and space. In addition, there is a shift in strategy in terms of transacting, marketing, and payment systems. Almost all business sectors today have adopted the use of digital technology with the implementation of online strategies. According to Lichtenthal and Eliaz (2003), business owners tend to effectively communicate with customers regarding the availability and purchase of their products through online platforms. This is one of the sole reasons many entrepreneurs now make use of online business strategies.

According to the Ministry of Communication and Information, shopping activities are no longer carried out by directly contacting the seller, and consumers rarely use cash for payment (Anonymous, 2016). There are approximately 19.5 billion Indonesians with the new habit of purchasing and selling goods online, which is known as e-commerce. Indonesia has experienced significant growth in online businesses in the last 3 years, with almost all sectors adopting digital technology, such as transportation, finance, tourism, culinary and retail services. Some business owners have officially closed part of their physical locations in the retail sector to focus on developing their online stores. For this reason, the two large retail companies in Indonesia that provide daily needs products have also developed their onlinebased business. The shift in strategy is associated with the fact that business owners seek ways to improve their service and maintain Consumer loyalty.

Online consumers are generally influenced by the external environment, demographics, personal characteristics, e-store features, beliefs, and behavioral intention. According to Li \& Zhang (2006), the internet 
acts as a shopping channel. It has been confirmed as a strong predictor in terms of security, risk, trust, convenience, control, website features, and Consumer service. Shim et al. (2002) stated that the easiness, speed, practicality, and flexibility of time in online transactions are the main factors leading to the shift from public to online shopping. Nevertheless, this new means of purchasing items over the internet is also not free from risks, such as product mismatch, damages during the delivery process, or physical friction between products.

Behavioral intention is a consumer's intention to carry out an activity in the future. Beck and Kenning (2015) stated that consumer's behaviour intention to purchase new products is influenced by the seller's reputation and the consumer's confidence level. This is because consumer behavior is predictable from their intentions. Zeithaml (1988) stated that a person's intention to carry out an activity is a dimension of their future behavior. This is also supported by Ajzen and Fishbein's (1980) research, which stated that behavioral intention is correlated with actual behavior. They further explained that online consumers' behavior significantly depends on the availability of information, the website's attractiveness, and the ease of making online transactions.

Attitude is closely related to the intention of one's behavior, and it is categorized into 3 dimensions by Breckler (1984), namely cognitive, affective, and conative. The cognitive dimension refers to a person's belief in an object, while affective is associated with the stimuli feeling in one's heart. Meanwhile, the conative dimension refers to a person's behavior over an object. The attitude of online shopping is basically a person's response to a purchase transaction activity. Therefore, whether strong or weak, the desire of someone to purchase products online is dependent on the accumulation of easiness and risk (Yu and $\mathrm{Wu}, 2007$ ).

Convenience in online transactions is an activity that does not bother the consumer when making online transactions (Davis, 1989). The ease in a transaction can be in the form of ordered procedures, fast product delivery process, speed, and service accuracy. Consumers feel delighted while shopping online when they conveniently make transactions (Pikkarainen et al., 2004). Meanwhile, the risk associated with online transactions is experienced by consumers during transactions. The risk associated with the nonconformity of an ordered product with the displayed image is usually due to undelivered items, loss, delay, etc (Turban et al., 2004).

The existence of convenience factors as well as risks in online transactions or purchases is the basis for consumer attitudes toward the trend of online shopping. Therefore, this study aims to measure the relationship between convenience and risk of online transactions towards consumer behavior intentions to purchase daily needs products through the online store channel.

\section{METHOD}

This research was carried out from July to August 2018 with the population consisting of consumers dealing with online selling and purchasing transactions, through website and android-based applications. Data were randomly obtained from 218 online store consumers spread across various regions in Indonesia.

The object were consumers of daily needs products, such as kitchen products, snacks, beverages, toiletries \& washers, sanitary napkins, cigarettes, etc. Furthermore, the study population consists of people that purchased products online, through some platforms such as lazada, tokopedia, blibli, blanja, elevenia, etc. However, due to a large number of populations, the purposive random sampling technique was used to determine those that made online shopping transactions.

The data obtained from the respondents were tested for normality, validity, and reliability using SPSS software. Out of 218 respondents, 161 met the requirements for further analysis using AMOS v23 software. The survey results showed that only $23 \%$ of the respondents purchased daily needs products via online store channels, while $77 \%$ utilized other channels. Furthermore, out of the 161 respondents, $71 \%$ were female, and the remaining $29 \%$ were male. Approximately $98 \%$ were above 18 years, $66 \%$ had high educational backgrounds, and more than $51 \%$ were employed with fixed income.

This is a causal research aimed to analyze the relationships between one variable and another as well as how they influence each other. The latent variables analyzed in this study are the perceptions on easiness and the convenience of carrying out online transactions (Pikkarainen et al., 2004; Shen and Demoss, 2012), risks associated with the process (Adi, 2013; Williams, 2012), consumers' attitudes (Prasad and Aryasri 2009) and behavioral intentions ( $\mathrm{Li}$ and Zhang, 2006; Rong et al., 2011; Zabkar et al.,2010). Indicators of each variable are shown in Table 1. 
Table 1. Variables and indicators of consumer behavior intentions

\begin{tabular}{|c|c|}
\hline Variables & Indicators \\
\hline Transaction convenience (TC) & $\begin{array}{l}\text { 1. Easy of shopping }\left(\mathrm{TC}_{1}\right) \\
\text { 2. Easy of payment }\left(\mathrm{TC}_{2}\right) \\
\text { 3. Easy of order/delivery }\left(\mathrm{TC}_{3}\right) \\
\text { 4. Quality of Consumer service }\left(\mathrm{TC}_{4}\right)\end{array}$ \\
\hline Transaction Risk (TR) & $\begin{array}{l}\text { 1. Poor services }\left(T R_{1}\right) \\
\text { 2. payment failure }\left(T R_{2}\right) \\
\text { 3. Order/delivery failure }\left(T R_{3}\right) \\
\text { 4. No purchase guarantee }\left(T C_{4}\right) \\
\text { 5. No personal data security }\left(\left(T R_{5}\right)\right.\end{array}$ \\
\hline Attitude (Att.) & $\begin{array}{l}\text { 1. Fondness on online shopping }\left(A t t_{1}\right) \\
\text { 2. Accordance to lifestyle }\left(A t t_{2}\right) \\
\text { 3. Perception on making work easier }\left(A t t_{3}\right) \\
\text { 4. Perception on the efficiency of time }\left(A t t_{3}\right)\end{array}$ \\
\hline $\begin{array}{l}\text { Behavioral Intention (BI) to purchase daily needs } \\
\text { products through the online store channel }\end{array}$ & $\begin{array}{l}\text { 1. Intention to install the online store channel }\left(\mathrm{BI}_{1}\right) \\
\text { 2. Intention to use the online store channel }\left(\mathrm{BI}_{2}\right) \\
\text { 3. Intention to purchase cooking needs via online channel }\left(\mathrm{BI}_{3}\right) \\
\text { 4. Intention to purchase food and beverage via online channel }\left(\mathrm{BI}_{4}\right) \\
\text { 5. Intention to purchase toiletries via online channel }\left(\mathrm{BI}_{5}\right) \\
\text { 6. Intention to purchase personal needs via online channel }\left(\mathrm{BI}_{6}\right) \\
\text { 7. Intention to purchase all of daily needs via online channel }\left(\mathrm{BI}_{7}\right) \\
\text { 8. Intention to spread the online store channel }\left(\mathrm{BI}_{8}\right) \\
\text { 9. Intention to recommend the online store channel to others }\left(\mathrm{BI}_{9}\right)\end{array}$ \\
\hline
\end{tabular}

The relationship between the variables and indicators above is analyzed using the Structural Equation Modeling (SEM) method to determine the relationship between latent variables and provide answers to the hypotheses constructed. This method is carried out in stages to obtain the model's goodness of fit. Furthermore, this approach is suitable for populations with limited variable, therefore, the data or results of the research are considered a representation of the entire population.

To obtain the optimal Goodness of Fit value, the author modified the pathways between several

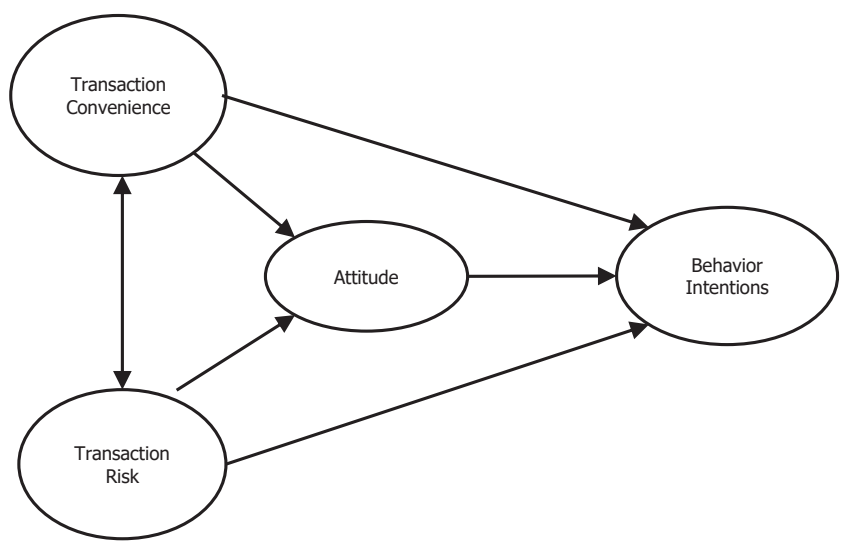

Figure 1. Structure model of consumer behavior intention indicators. The pathway's addition is based on the modification indices in the AMOS program with a theoretical basis. According to Zeithaml (1988), the intention of someone related to something is one of the future behavior dimensions.

Based on the existing theoretical basis, the four variables' interrelationships are arranged as shown in Figure 1. The hypotheses proposed and analyzed in this study are as follows:

$\mathrm{H}_{1}$ : The transaction convenience affects the attitude of consumers in online store channel,

$\mathrm{H}_{2}$ : The transaction risk affects the attitude of consumers in online store channel,

$\mathrm{H}_{3}$ : The transaction convenience affects the behavior intention to purchase daily needs through online store channel,

$\mathrm{H}_{4}$ : The transaction risk affects the behavior intention to purchase daily needs through online store channel,

$\mathrm{H}_{5}$ : The attitude of online shopping affects the behavior intention to to purchase daily needs through online store channel.

\section{RESULT AND DISCUSSION}

The authors carried out a measurement model analysis to examine the validity and reliability of 
empirical indicators that form the endogenous and exogenous latent variables. The measurement model is analyzed through the Confirmatory Factor Analysis (CFA) technique by examining the value of the loading factor in the model produced. According to Nunally et al. (1994), indicator variables are very influential when the loading factor value is above 0.5 . Therefore, using AMOS v.23 software, measurement results are obtained, as shown in Figure 2.

Based on the model produced in Figure 2, it is known that some indicators have a weak influence on the latent variable, which is indicated by the value of the loading factor less than 0.5. The indicators with offending estimates are $\mathrm{TC}_{1}$ (ease of shopping), $\mathrm{TC}_{4}$ (quality of Consumer service), $\mathrm{Att}_{5}$ (service), and $\mathrm{Att}_{6}$ (risk). This means that the empirical indicators of $\mathrm{TC}_{1}$ and $\mathrm{TC}_{4}$ and Att5 and Att6 are not strong enough to explain the convenience of a transaction and Attitude variables, respectively. Therefore, the indicator is removed from the model.

Furthermore, to obtain the optimal Goodness of Fit value, the pathways between several indicators, namely
$\mathrm{BI}_{1}, \mathrm{BI}_{8}$ and $\mathrm{BI}_{9}, \mathrm{BI}_{2}$ and $\mathrm{BI}_{6}, \mathrm{BI}_{4}$ and $\mathrm{BI}_{5}, \mathrm{BI}_{5}$ and $\mathrm{BI}_{6}, \mathrm{BI}_{6}$ and $\mathrm{BI}_{8}$, as well as $\mathrm{BI}_{8}$ and $\mathrm{BI}_{9}$ are modified. The addition of these pathways is based on the modification indices results in the AMOS program with a theoretical basis. According to Zeithaml (1988), someone's intention to a product is one of the dimensions of future behavior. This is also supported by the research carried out by Ajzen and Fishbein (1980), which found that behavior intention is correlated to actual behavior, as shown in Figure 3.

A structural model analysis is carried out to determine the relationship between latent variables and provide answers to the hypotheses constructed. It was carried out in stages to get the model's goodness of fit. The structural model is good when it fulfills the goodness of fit criteria (Hair et al., 2010), as shown in Table 2. The chi-square value is $169,889 \leq 177.39$, probability is $0.105 \geq 0.05$, GFI is $0.909 \geq 0.90$ and $0.991 \geq 0.90$, while the value of RMSEA is $0.031 \leq 0.08$ and AGFI is 0.87 close to 0.90 . This shows that the overall model is acceptable and can be used to analyze hypotheses.

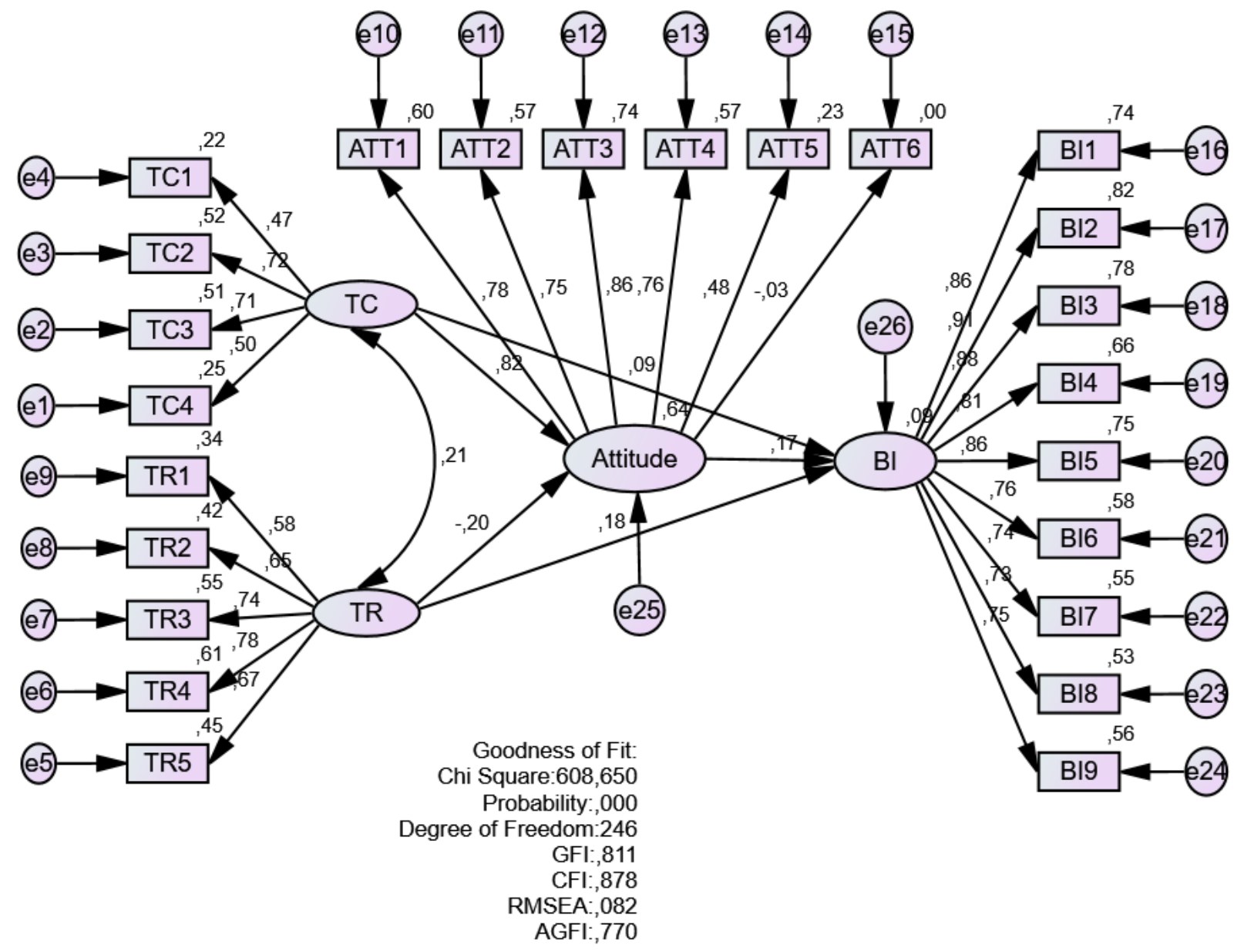

Figure 2. Indicator measurement of consumer behavior intention 
Table 2. Goodness of fit indices

\begin{tabular}{lccc}
\hline \multicolumn{1}{c}{ Indices } & Values & Cut-off values & Goodness of Fit \\
\hline Chi-square & 169,889 & (s chi-square of table, 177.39) & Good \\
Probability & 0.105 & $\geq 0.05$ & Good \\
GFI (goodness of fit index) & 0.909 & $\geq 0.90$ & Good \\
CFI (comparative fit index) & 0.991 & $\leq 0.95$ & Good \\
RSMEA (the root mean square error of approximation) & 0.031 & 0.08 & Good \\
AGFI (adjusted goodness of fit index) & 0.87 & $\geq 0.90$ & Fair \\
\hline
\end{tabular}

Table 3. Variable Relationship to purchase daily needs

\begin{tabular}{lccc}
\hline & Correlation & Estimates & Hypotheses \\
\hline Transaction convenience (TC) - -> Attitude (Att) & 0.88 & Accepted \\
Transaction convenience (TC) --> Behavior intention (BI) & 0.64 & Accepted \\
Transaction Risk (TR) & $-->$ Attitude (Att) & -0.11 & Denied \\
Transaction Risk (TR) & $-->$ Behavior intention (BI) & 0.21 & Denied \\
Attitude & $-->$ Behavior intention (BI) & 0.10 & Denied \\
\hline
\end{tabular}

The model in Figure 3 and the standardized regression weights in Table 3 showed that the "Transaction Convenience" is strongly influenced by "Attitude" and "Behavior intention," with the estimated loading factor value above 0.5 . This means that the perception of transaction convenience, especially the ease of payment and delivery service, has a positive and significant effect on consumers' attitude and behavior intention to use online store channel to purchase their daily needs product. This is contrary to transaction risk, which does not affect attitude and behavior intention to use online store channel. These results are aligned with the research conducted by Roy et al. (2018), which stated that the perception of ease of using online store channel positively affects consumers' attitudes and intentions.

The evolution of the digital era has led to the emergence of new behavior in shopping activities. According to Wahyudin and Azali (2020), online shopping has become consumers' habit, especially in terms of selling and purchasing products. Approximately $21 \%$ of online shop application users purchase their daily needs using various online software. The daily needs referred to in this study are those needed in everyday activities that tend to run out with a short time (1-7 days), such as cooking needs, foods, snacks, beverages, toiletries, and laundries. Furthermore, Wahyudin and Azali (2020) stated that the characteristics of the consumer are dominated by young people between the ages of 18-35, with the majority of employees with monthly income above Rp2,000,000. This is in line with the report released by Tetra Pax, which stated that the growth of global retail business FMCG by $17.4 \%$ from 2017-2022 occurred in the sales of the online grocery (The Tetra Pax Index Report Online, 2018).

\section{CONCLUSION}

In conclusion, consumers' intention to shop online is dependent on the level of convenience and risk provided in an online store channel service. The ease and convenience of consumers during transactions, especially in terms of payment and delivery service, have a positive and significant effect on their attitude and behavioral intention to continuously use the online store channel to purchase daily needs product. However, transaction risk does not have an effect on attitude and behavior intention to use online store channel. Therefore, only the first and second hypotheses $\left(\mathrm{H}_{1}\right.$ and $\mathrm{H}_{2}$ ) were accepted, while $\mathrm{H}_{3}, \mathrm{H}_{4}$ and $\mathrm{H}_{5}$ were rejected because they did not meet the requirements.

\section{CONFLICT OF INTEREST}

The authors declare that there is no conflict of interest regarding to the publication of this article.

\section{REFERENCES}

Ajzen, I., \& Fishbein, M. (1980). Understanding Attitudes and Predicting Social Behaviour. Eaglewood Cliffs, NJ: Prentice-Hall. 
Anonymous. (2016). Gerakan nasional 1000 starup digital. Retrieved on December $18^{\text {th }}$, 2018. http://aptika. kominfo.go.id/index.php/artikel/145-gerakannasional1000-startup-digital

Beck, S., \& Kenning, P. (2015). The Influence of Retailers' Family Firm Image on New Product Acceptance: An Empirical Investigation in the German FMCG Market. International Journal of Retail \& Distribution Management, 43(12), 1126-1143. https://doi. org/10.1108/IJRDM-06-2014-0079

Breckler, S. J. (1984). Empirical validation of affect, behavior, and cognition as distinct components of attitude. Journal of Personality and Social Psychology, 47(6), 191-205. https://doi.org/10.1037//0022-3514.47.6.1191

Davis, F. D. (1989). Perceived usefulness, perceived ease of use, and user acceptance of information technology. MIS Quarterly, 13(2), https://doi.org/318-340. $10.2307 / 249008$

Hair, J. F., Black, W. J., Babin, B. J., \& Anderson, R. E. (2010). Multivariate data analysis, a global perspective. New Jersey: Pearson Prentice Hall.

Li, N., \& Zhang, P. (2006). What makes customers shop online? The technology of electronic customer relationship management. India: Pearson.

Lichtenthal, J. D. \& Eliaz, S. (2003). Internet integration in business marketing tactics. Industrial Marketing Management, 32 (1), 3-13.

Nunally J.C, Bernstein, IH. (1994). Psysikometric theory (3 rd.ed). NEW YORT, Mc, Graw-Hill.

Pikkarainen, T., Pikkarainen, K., Karjaluoto, H., \& Pahnila, S. (2004). Consumer acceptance of online banking: An extension of the technology acceptance model. Internet Research, 14 (30), 224-235. https://doi. org/10.1108/10662240410542652

Prasad, C. \& Aryasri, A. (2009). Determinants of shopper behavior in e-tailing: An empirical analysis. Paradigm, 13 (1), 73-83. https://doi.org/10.1177/0971890720090110

Rong, J., Vu, H. Q., Law, R., \& Li, G. (2011). A behavioral analysis of web sharers and browsers in Hong Kong using targeted association rule mining. Tourism Management, 33 (4), 731-740. https://doi.org/10.1016/j. tourman.2011.08.006
Roy, Sanjit Kumar, M.S. Balaji, Ali Quazi \& Mohammed Quaddus. 2018. Predictors of Customer Acceptance and Resistance to Smart Technologies In The Retail Sector. Journal of Retailing and Consumer Services, 147-160. https://doi.org/10.1016/j.jretconser.2018.02.005

Shen, Y., Li, S., \& Demoss, M. (2012). The effect of quantitative electronic word of mouth on consumer perceived product quality. International Journal of Management and Marketing Research. 5, 19-30.

Shim, J. P., Shin, Y. B., \& Nottingham, L. (2002). Retailer web site influence on customer shopping: An exploratory study on key factors of customer satisfaction. Journal of the Association for Information Systems, 3, 53-76.

The Tetra Pak Index Report Online. (2018). Insight and Opportunity: Online Grocery. Tetra Pak Group. USA

Turban, E., King, D., Lee, J., \& Viehland, D. (2004). Electronic commerce: A managerial perspective. New Jersey: Pearson Prentice Hall.

Wahyudin, M \& Azali, F Nahar. (2020). Consumer shopping behavior through online store for food and beverages. IOP Conf. Ser:: Earth Environ. Sci. 425 (1), 012026. https://doi.org/10.1088/1755-1315/425/1/012026

Williams, M. (2012). Relating word-of-mouth to corporate reputation. Public Communication Review, 2, 3-16. https://doi.org/10.5130/pcr.v2i2.2590

Yu, T. \& Wu, G. (2007). Determinants of internet shopping behavior: an application of reasoned behavior theory. International Journal of Management, 24 (4), 744-762.

Zabkar, V., Brencic, M. M., \& Dmitrovic, T. (2010). Modelling perceived quality, visitor satisfaction, and behavioral intentions at the destination level. Tourism Management, 31 (4), 537-546. https://doi.org/10.1016/j. tourman.2009.06.005

Zeithaml, V. A. (1988). Consumer perceptions of price, quality and value: a means-end model and synthesis of evidence. Journal of Marketing, 52 (3), 2-22. https://doi. org/10.2307/1251446 